\title{
Świątynia nauki, fundament demokracji czy fabryka specjalistów? Józef Chałasiński i powojenne spory o ideę uniwersytetu ${ }^{1}$
}

Pierwsze lata powojennej historii Polski były czasem przełomowym, czasem niepewności i nadziei na nowe społeczeństwo. Wielu intelektualistów wierzyło w unikalną szansę na zmiany i budowę lepszego świata, w tym budowę nowoczesnego uniwersytetu. Tradycje międzywojennej akademii starły się z ideami tworzenia uczelni nowego typu - modernizacyjne sny przybierały różne formy, konfrontując środowiska bardziej radykalne z umiarkowanymi. Wkrótce uniwersytety zostały przekształcone w miejsca istotne dla władz, gdzie tworzono nową wykładnię historii, zaplecze ideologiczne Partii i nową elitę kraju. W niniejszej pracy koncentrujemy się na postaciach Józefa Chałasińskiego i Tadeusza Kotarbińskiego, których drogi zbiegły się w 1945 roku w robotniczej Łodzi - miejscu budowy nowego uniwersytetu na nowe czasy. Analizując ich wypowiedzi prasowe, przemówienia i artykuły naukowe rekonstruujemy modele uniwersytetów, mające stanowić propozycje ukształtowania nowej uczelni w zmieniających się ramach polityczno-społecznych.

Słowa kluczowe: Józef Chałasiński, modele uniwersytetu, stalinizm, powojenna Polska, Łódź.

1 Autorzy dziękują prof. Kazimierzowi Kowalewiczowi, prof. Kai Kaźmierskiej, a także Krystianowi Szadkowskiemu, Wiktorowi Marcowi i Piotrowi Juskowiakowi z redakcji „Praktyki Teoretycznej” za lekturę pierwszej wersji niniejszego tekstu i szereg krytycznych uwag, które pozwoliły uczynić go lepszym. Projekt został sfinansowany ze środków Narodowego Centrum Nauki przyznanych na podstawie decyzji nr DEC2011/03/N/HS6/01948. 
Dla wielu spośród środkowoeuropejskich intelektualistów pierwsze lata po II wojnie światowej były czasem wielkich oczekiwań. Perspektywa próby modernizacyjnego skoku i realizacji radykalnych reform społecznych działała na wyobraźnię i popychała do działania, nawet jeśli w stosunku do nowych władz zachowywano pewien dystans i rezerwę. Jednak tak rozpowszechnione wówczas nadzieje, że możliwe będzie uzyskanie przez społeczeństwo wpływu na kierunek i kształt dokonujących się przemian, okazały się tylko złudzeniem. Stalinowska modernizacja była projektem odgórnym, realizowanym bez liczenia się z reformatorskimi projektami zrodzonymi poza elitą władzy. Koszty zaangażowania z czasem stawały się coraz wyższe, a poczucie rozczarowania bardziej dojmujące. Powojenna rewolucja jednak zawiodła oczekiwania większości lewicujących intelektualistów.

To pokoleniowe doświadczenie stało się również udziałem Józefa Chałasińskiego, znakomitego socjologa i jednego spośród tych, którzy z największym zapałem zaangażowali się w przemiany rozpoczęte w polskiej nauce tuż po wojnie. Włodzimierz Więcławski oceniając po latach rolę odegraną wówczas przez Chałasińskiego, pisał:

\section{Chałasiński} w pierwszych latach powojennych nie był jedynie posłusznym realizatorem scenariusza władz, prowadzących własną grę polityczną, lecz próbował w aktywny sposób wpływać na kierunek dokonujących się po wojnie przemian
Profesor bezpartyjny, „prawdziwy”, „przedwojenny”, a i „postępowy” oraz „lewicujący”, przy tym posłuszny władzy totalitarnej i przyjmujący rolę w zgodzie z jej scenariuszem, był dla tej władzy znakomitym atutem w grze politycznej. Pragnąc zniszczyć - przypomnijmy - „reakcyjny” Kraków wzniesiono nieopodal grodu Jagiellonów Nową Hutę. Analogiczną rolę wobec „reakcyjnej” profesury Uniwersytetu Jagiellońskiego miał odegrać nowy rektor, Józef Chałasiński.

Nie odegrał jej jednak, gdyż nie przyjął propozycji objęcia stanowiska rektora, o której tu mowa. Zasłaniając się „łódzkim patriotyzmem”, Chałasiński odrzucił ofertę przenosin i prestiż wiążący się z fotelem rektora najstarszej uczelni w Polsce. To robotnicza Łódź, a nie posiadający wielowiekowe tradycje akademickie Kraków, powinna jego zdaniem stać się laboratorium, w którym narodzić miał się „uniwersytet uspołeczniony" - nowy, odpowiadający wyzwaniom powojennej modernizacji, model uniwersytetu.

Wbrew temu, co zdaje się sugerować w przytoczonym cytacie Wincławski, Chałasiński w pierwszych latach powojennych nie był jedynie posłusznym realizatorem scenariusza władz, prowadzących własną grę polityczną, lecz próbował w aktywny sposób wpływać na kierunek dokonujących się po wojnie przemian. Jak wielu przedwojennych intelektualistów o lewicowych poglądach, łączył z nimi duże nadzieje. Wierzył, że w nowych, powojennych warunkach możliwe będzie nadanie 
szkolnictwu wyższemu zdecydowanie egalitarnego charakteru i uczynienie uniwersytetu jednym z motorów przełamującej wielowiekowe zapóźnienie modernizacji. Celem niniejszego artykułu będzie analiza wspomnianej już wizji „uniwersytetu uspołecznionego”, którą uznajemy za przykład projektu radykalnie lewicowej, niejako „oddolnej”, wytworzonej niezależnie od urzędowej ideologii, reformy społecznej. Żyzny grunt dla tego typu projektów zrodziła dokonująca się po wojnie rewolucja, niosąca ze sobą obietnicę modernizacyjnego zrywu i stymulująca wyobraźnię lewicowo zorientowanych reformatorów. Z czasem jednak, niemal niepostrzeżenie, ich modernizacyjne wizje zaczęły się mieszać z nabierającą urzędowej mocy ideologią, a zaangażowanie stawało się niebezpiecznie bliskie bieżącym politycznym rozgrywkom. Stalinizm, ku któremu - patrząc krótkoterminowo - wiodła powojenna rewolucja, oznaczał klęskę oddolnych projektów reform. Paradoksalnie to, co stanowiło warunek możliwości ich zaistnienia, było jednocześnie warunkiem niemożliwości ich realizacji.

Podjęty przez nas temat zawieszony jest między makrostrukturalnymi procesami politycznymi i społecznymi (powojennymi reformami, politykami naukowymi, stalinizacja) a jednostkowym losem - powojenną biografią intelektualisty. Chałasińskiego traktujemy jako postać, której losy w pewien sposób odzwierciedlają dylematy lewicującej inteligencji w pierwszych powojennych latach. Przykład Chałasińskiego znakomicie pokazuje, że biografia jednostki, skoncentrowana na intelektualnych wyborach i ideowych dylematach, pozwala uchwycić w skondensowany sposób pewne szersze procesy, stając się tym samym cennym uzupełnieniem (często polemicznym) dla opracowań skoncentrowanych na zmianach instytucjonalnych i analizie ilościowej.

Nietrudno zauważyć, że proponowany przez nas sposób ujęcia roli Chałasińskiego w dyskusji nad powojennymi politykami naukowymi i jego udziału w ich wdrażaniu wyraźnie różni się od perspektyw przyjmowanych przez literaturę przedmiotu. Dominujące podejście, które moglibyśmy nazwać makrostrukturalnym, koncentruje się na państwowej polityce naukowej i procesie odbudowy szkolnictwa wyższego po wojnie, marginalnie traktując dylematy i wybory zaangażowanych w te procesy jednostek. Przywołać należy tutaj prace Piotra Hubnera szczegółowo rekonstruujące polityczny i organizacyjny kontekst powojennych przemian ${ }^{2}$; a także odpowiedni tom monumentalnej Historii

2 P. Hübner, Polityka naukowa w Polsce w latach 1944-1953: Geneza systemu, Wrocław 1992; tegoż, Sita przeciw rozumowi: losy Polskiej Akademii Umiejętności w latach 1939-1989, Kraków 1994; tegoż, Kongres Nauki Polskiej jako forma realizacji zatożeń polityki naukowej państwa ludowego, Wrocław 1983.
Wierzył, że w nowych, powojennych warunkach możliwe będzie nadanie szkolnictwu wyższemu zdecydowanie egalitarnego charakteru i uczynienie uniwersytetu jednym z motorów przełamującej wielowiekowe zapóźnienie modernizacji 
nauki polskiej, w którym jedynie zdawkowo potraktowano toczone w pierwszych powojennych latach dyskusje na temat kształtu reformy szkolnictwa wyższego ${ }^{3}$. O samym procesie restrukturyzacji systemu szkolnictwa wyższego w okresie powojennym w państwach bloku radzieckiego pisał w sposób najbardziej kompleksowy John Connelly ${ }^{4}$ Oprócz tego wspomnieć należy o sporej grupie prac poświęconych omówieniu kondycji poszczególnych dyscyplin w pierwszej powojennej dekadzie, skupiających się zazwyczaj na ideologicznej presji, jakiej poddawane było środowisko naukowe - przykład stanowić mogą choćby publikacje Rafała Stobieckiego poświęcone stalinizacji polskiej nauki historycznej5.

Jeśli chodzi o aktywność samego Chałasińskiego, to istniejącą literaturę podzielić można w zasadzie na dwie grupy. Pierwszą tworzą prace poświęcone powstaniu i pierwszym latom Uniwersytetu Łódzkiego, dające przede wszystkim szersze tło historyczne i odnoszące się głównie do organizacyjnej działalności Chałasińskiego. Wymienić należy tutaj przede wszystkim publikacje Bohdana Baranowskiego ${ }^{6}$ oraz pracę zbiorową o charakterze sprawozdawczym pod redakcją Antoniny Kłoskowskiej . Drugą grupę publikacji stanowią poświęcone Chałasińskiemu prace o charakterze biobibliograficznym ${ }^{8}$ bądź zbiorowe tomy inspi-

3 Historia Nauki Polskiej - wiek XX, oprac. zbiorowe, Warszawa 1995; J. Chodakowska, Rozwój szkolnictwa wyższego w Polsce Ludowej w latach 1944-1951, Wrocław 1981; B. Krasiewicz, Odbudowa szkolnictwa wyższego w Polsce Ludowej w latach 1944-1948, Wrocław 1976; B. Jaczewski, Życie naukowe w Polsce w drugiej potowie XIX i wXX wieku: Organizacje i instytucje, Wrocław 1987; Janina Chodakowska, Rozwój szkolnictwa wyższego w Polsce Ludowej w latach 1944-1951, Wrocław 1981.

4 J. Connelly, The Foundation of Diversity: Communist Higher Education Policies in Eastern Europe 1945-1955, w: Science Under Socialism, Cambridge 1999; J. Connelly, Captive University: The Sovietization of East German, Czech and Polish Higher Education 1945-1956, Chapel Hill 2000.

5 Zob. R. Stobiecki, Historia pod nadzorem: Spory o nowy model historii w Polsce (II potowa lat czterdziestych - początek lat pięćdziesiątych, Łódź 1993.

6 B. Baranowski, Pierwsze lata Uniwersytetu Łódzkiego, 1945-1949, Łódź 1985; B. Baranowski, K. Baranowski, Trudne lata Uniwersytetu Eódzkiego (1949-1956), Łódź 1990; K. Baranowski, Początki Łodzi akademickiej, Łódź, 1993. Krytykę tych opracowań można znaleźć w: A. Czyżewski, Łódź akademicka, w: Rok 1945 w Łodzi: Studia i szkice, Łódź, 2008.

7 A. Kłoskowska, Uniwersytet Łódzki 1945-1970, Warszawa 1970.

8 Cz. Gryko, Józef Chatasinski - cztowiek i dzieto: Od teorii wychowania do kulturowej wizji narodu, Lublin 2007; A. Kaleta, Józef Chatasiński - socjolog i humanista, Toruń 1980; W. Wincławski, Wprowadzenie do Chatasińskiego: Przewodnik bio-bibliograficzny, Toruń 1989; tegoż, Stownik biograficzny socjologii polskiej, Warszawa 2001. 
rowane jego postacią i badaniami ${ }^{9}$. We wszystkich tych pracach, jakkolwiek podejmują one problematykę ściśle wiążącą się z przedmiotem niniejszego artykułu, umyka zupełnie lub marginalnie potraktowany jest problem, który chcemy postawić w centrum naszych rozważań - rozbudzonych przez powojenną rewolucję nadziei na radykalną reformę uniwersytetu (wraz z będącą odpowiedzią na to wyzwanie wizją „uspołecznionego uniwersytetu” Chałasińskiego), ich klęski i będącego jej konsekwencją niezamierzonego, paradoksalnego „wspólnictwa” w dziele stalinizacji polskiej nauki ${ }^{10}$.

\section{Powojenna rewolucja a uniwersytet}

Uniwersytecka mapa Drugiej Rzeczypospolitej obejmowała sześć miast: Warszawę, Kraków, Wilno, Lwów, Poznań oraz będący siedzibą katolickiego uniwersytetu Lublin. Oprócz uniwersytetów, działało jeszcze ponad trzydzieści szkół wyższych - politechniki, różnego rodzaju akademie i uczelnie profilowane (np. Akademia Górnicza w Krakowie, Szkoła Główna Handlowa w Warszawie itd.) oraz szczególnie ważna z punktu widzenia naszego tekstu niepaństwowa uczelnia humanistyczna o lewicowo-liberalnym obliczu - Wolna Wszechnica Polska działająca od 1919 roku w Warszawie ${ }^{11}$. Kondycja polskiej nauki przed wojną nie była najlepsza. Największą przeszkodą były oczywiście ograniczone środki finansowe, co często skutecznie blokowało rozpoczęcie kariery uniwersyteckiej wielu młodym badaczom i utrudniało rozwój nauk eksperymentalnych. W latach trzydziestych narastały również problemy polityczne. Z jednej strony rósł nacisk aparatu państwowego na, zazwyczaj nastawione opozycyjnie (sympatyzujące często z narodową prawica), środowisko naukowe, czego najlepszym wyrazem była nowa ustawa o szkolnictwie wyższym z 1933 roku $^{12}$, z drugiej zaś uczelnie stawały się arenami antysemickich

9 Bunty i stużebności uczonego: Profesor Józef Chatasiniski, red. L. Wojtczak, Łódź 1992; A. Kaleta, Chatasiński dzisiaj: Materiaty z konferencji naukowej, Toruń 1996.

10 Najbliższy powyższej tematyce okazał się krótki artykuł o charakterze popularnonaukowym autorstwa wspomnianego Piotra Hübnera, poświęcony wzajemnym relacjom dwóch pierwszych rektorów UŁ, Tadeusza Kotarbińskiego i właśnie Chałasińskiego, zob. P. Hübner, Kotarbiński versus Chatasiński, „Forum Akademickie” 2011, nr 4, http://forumakademickie.pl/fa/2011/04/kotarbinski-versus-chalasinski/.

11 Zob. K. Baranowski, Alternatywna edukacja w II Rzeczypospolitej: Wolna Wszechnica Polska, Warszawa 2001; Z. Skubała-Tokarska, Spoteczna rola Wolnej Wszechnicy Polskiej, Warszawa-Kraków 1967.

12 Najważniejsze zmiany, jakie przyniosła reforma z 1933 roku, to: nadanie Ministrowi Wyznań Religijnych i Oświecenia Publicznego prawa do zatwierdzania 
awantur wszczynanych przez nacjonalistyczną młodzież, tradycyjnie posiadającą na polskich uniwersytetach znaczne wpływy ${ }^{13}$.

Przyznać trzeba, że przedwojenny uniwersytet był instytucją dość konserwatywną, zarówno pod względem światopoglądowym i metodologicznym, jak i społecznym. Studenci rekrutowali się głównie z środowisk ziemiańskich, burżuazyjnych i inteligenckich ${ }^{14}$, a jedną z popularniejszych form zrzeszania były cieszące się nienajlepszą sławą korporacje; w oczach lewicowo zorientowanej części opinii publicznej korporanci symbolizowali „złotą młodzież”, zdobywającą dyplomy wiele lat po przewidzianym terminie, skorą do bójki i hulanek, traktującą studia raczej jako czas przyjemności i zabawy, niż jako okres wytężonej nauki i pracy.

Sześć lat wojny na zawsze przekreśliło tamten świat. Zmiana granic, gwałtowna przebudowa struktury społecznej, związana m.in. z zagładą Żydów, przymusowym przesiedleniem Niemców, eksterminacją polskiej inteligencji; oraz przemiany polityczne - wszystko to pozwala mówić o dokonanej wówczas w Polsce rewolucji. Andrzej Leder w jednym ze swoich esejów pisze:

W Polsce w latach 1939-1956 dokonała się rewolucja społeczna. Okrutna, brutalna, narzucona z zewnątrz, ale jednak rewolucja. Ta rewolucja niesłychanie głęboko przeorała tkankę polskiego społeczeństwa, tworząc warunki dla dzisiejszej ekspansji klasy średniej, czyli mieszczaństwa, do najgłębszej być może od wieków zmiany mentalności Polaków: odejścia od mentalności określonej przez wieś i folwark ku zdeterminowanej przez miasto i miejski sposób życia ${ }^{15}$.

wybieranych przez uczelnie rektorów, likwidowania i tworzenia wydziałów, katedr i zakładów, przedłużenie kadencji rektorów do 3 lat oraz ograniczenie kompetencji senatów uczelnianych. Ustawa znacznie poszerzała kompetencje Ministra, wiele spraw ujętych było w niej w sposób ramowy, co jeszcze powiększało możliwość interwencji władz administracyjnych w życie uczelni. Ustawa spotkała się z protestem środowisk akademickich; jej konsekwencją było m.in. przeniesienie na wcześniejszą emeryturę części profesorów znanych z opozycyjnego stanowiska wobec rządu, a także likwidacja kilkudziesięciu katedr. Jednocześnie nowe nominacje na stanowiska rektorów i profesorów wyraźnie związane były z pozytywnym bądź co najmniej neutralnym stosunkiem kandydatów wobec władz (jedną z nowo tworzonych katedr objęła partnerka, a wkrótce później druga żona autora reformy, Janusza Jędrzejewicza).

13 Zob. M. Natkowska, Numerus clausus, getto tawkowe, numerus nullus, „paragraf aryjski": Antysemityzm na Uniwersytecie Warszawskim 1931-1939, Warszawa 1999.

14 Według szacunków Mariana Falskiego z 1937 roku, zaledwie około 20\% studentów na polskich uczelniach pochodziło z rodzin robotniczych i chłopskich. Odsetek ten był jeszcze niższy w wypadku uniwersytetów oraz uczelni o profilu artystycznym, zob. J. Lewandowski, Rodowód spoteczny powojennej inteligencji polskiej: 1944-1949, Szczecin 1991, s. 55-59.

15 A. Leder, Kto nam zabrat tę rewolucję?, „Krytyka Polityczna” 2011, nr 29, s. 32. 
Tę opinię filozofa i psychoanalityka przytoczyliśmy tutaj przede wszystkim ze względu na jej retoryczną siłę i stanowczość. Jednak sama jej treść nie odbiega od ocen formułowanych przez historyków, takich jak choćby Krystyna Kersten ${ }^{16}$, Michael Fleming ${ }^{17}$ czy Padraic Kenney ${ }^{18}$. Dwaj ostatni okres rewolucyjnych przemian ujmują nieco węziej - ich zdaniem w latach 1945-1947 miała miejsce w Polsce rewolucja społeczna, natomiast w latach 1948-1950 rewolucja polityczna, której zwieńczeniem była stalinizacja państwa i życia społecznego.

Rewolucja czy też rewolucje - zależnie od tego, czy przyjmiemy optykę Ledera, czy też Fleminga i Kenney’a - nieść musiała(y) ze sobą również głębokie zmiany w sferze nauki. Jeden z pierwszych studentów UŁ tak wspominał tamten czas:

\footnotetext{
Wybita, wytępiona inteligencja... Obliczam, że to nie te 30-40 tysięcy oficerów w Związku Radzieckim, ale [wymordowani] w obozach. W niszczeniu inteligencji przodowali i Sowieci i Niemcy. Trzeba było robić uniwersytety i chować tych ludzi. Ja pamiętam dokładnie, jak była mowa o tym, że jest za mało profesorów. Nie było lekarzy, nie było prawników, nie było inżynierów, nie było chemików. Nie było! Wszędzie były braki. Nikogo nie było! Przed nami było puste pole działania, myśmy wchodzili wszędzie gdzieśmy chcieli właściwie, trzeba się było tylko dobrze trzymać ${ }^{19}$.
}

Znajdziemy w tym cytacie w zasadzie wszystkie najważniejsze problemy, które dały o sobie znać w chwili, kiedy przystąpiono do powojennej odbudowy polskiej nauki. Odczuwano olbrzymie braki doświadczonej kadry ${ }^{20}$, która mogłaby objąć nowotworzone katedry i zakłady, w dużej mierze przerwana została również ciągłość instytucjonalna. Odmłodzenie ka-

16 K. Kersten, The Establishment of Communist Rule in Poland 1943-1948, Berkeley 1991.

17 M. Fleming, Communism, Nationalism and Ethnicity in Poland, 1944 1950, London-New York 2010.

18 P. Kenney, Rebuilding Poland: Workers and Communists 1945-1950, New York-London 2012.

19 Archiwum Wspomnień Łodzian, Adam Bukowczyk - wywiad biografic$z n y, 2010$ (zapis na potrzeby artykułu poddano drobnej modyfikacji).

20 Szacunkowo, przyjmuje się, ze zginęło 37\% osób z wyższym wykształceniem, a ubyło ok. 30\% ludzi nauki, czyli ok. 650-700 profesorów i pracowników naukowych, ponadto ponad 160 dawnych pracowników naukowych zdecydowało się pozostać na emigracji - K. Kersten, Między wyzwoleniem a zniewoleniem: Polska 1944-1956, Londyn 1993, s. 8-9; R. Stobiecki, Historia pod nadzorem, s. 38-39, R. Herczyński, Spętana nauka: Opozycja intelektualna w Polsce 1945-1970, Warszawa 2008, s. 41. 
Wszystko to sprawiało, że polska nauka jawić się mogła jako wielki plac budowy, stymulując wyobraźnię lewicowych intelektualistów. Można

było mieć nadzieję, że pukająca do bram uniwersytetu rewolucja

oznaczać będzie radykalne przekreślenie wszystkich słabości

konserwatywnej

i elitarnej

międzywojennej akademii dry naukowej stawało się koniecznością. Współgrało to zresztą z oczekiwaniami nowych władz względem uniwersytetów i naciskiem na społeczny awans części młodzieży robotniczej czy chłopskiej. Wszystko to sprawiało, że polska nauka jawić się mogła jako wielki plac budowy, stymulując wyobraźnię lewicowych intelektualistów. Można było mieć nadzieję, że pukająca do bram uniwersytetu rewolucja oznaczać będzie radykalne przekreślenie wszystkich słabości konserwatywnej i elitarnej międzywojennej akademii.

Ze względu na wspomniane przemiany przekształceniu uległa topografia polskiego świata akademickiego. Stare ośrodki uniwersyteckie Lwów i Wilno, znalazły się poza granicami Polski; o pewnej ciągłości można było mówić jedynie w przypadku Krakowa, Poznania, Lublina (KUL) oraz Warszawy, gdzie zresztą odbudowa uniwersytetu dokonywała się w najcięższych warunkach i przy pewnej obojętności ze strony władz. Nowe uniwersytety uruchomiono we Wrocławiu (miał kontynuować lwowskie tradycje akademickie), Toruniu (w znacznej mierze w oparciu o kadrę wileńskiego USB), w Lublinie, gdzie chciano w ten sposób zniwelować wpływy uczelni katolickiej, oraz w Łodzi. Charakterystyczne, że nowe władze nie były w stanie zapobiec wówczas reprodukcji zwartych, sięgających swoimi korzeniami głęboko w okres międzywojenny, środowisk akademickich. Jak zauważa Connelly, dowodziło to pewnej słabości polskich komunistów, nieposiadających dostatecznych wpływów i siły politycznej, aby móc zaryzykować skuteczne przeciwdziałanie rekonstrukcji przedwojennych elit ${ }^{21}$.

\section{Wiedza i praca - uniwersytet w robotniczej Łodzi}

$\mathrm{Na}$ tle innych ośrodków akademickich, posiadających zazwyczaj bogate tradycje naukowe, robotnicza Łódź wyraźnie się wyróżniała. Choć na fali dziewiętnastowiecznej industrializacji wyrosła na drugi największy ośrodek miejski na ziemiach polskich, aż do momentu wybuchu II wojny światowej nie wykształciło się tutaj silne środowisko inteligenckie ani nie powstała żadna uczelnia wyższa ${ }^{22}$. Szereg podjętych prób mających na celu powołanie tutaj wyższej uczelni zakończyło się niepowodzeniem, niezależnie od tego, czy decyzję podejmować miała carska administracja, niemieccy okupanci czy władze Drugiej Rzeczy-

21 J. Connelly, Captive University; tegoż, The Foundation of Diversity.

22 Zob. K. Baranowski, Inteligencja tódzka w latach II Rzeczypospolitej, Łódź 1996. 
pospolitej. Przyczyny odmowy były różne, wydaje się jednak, że pośród nich niemałą rolę odgrywać mogła obawa przed stworzeniem intelektualnego zaplecza dla radykalnych ruchów robotniczych, posiadających w Łodzi niemałe wpływy.

Formalnie Łódź awansowała do rangi ośrodka akademickiego już w 1928 roku, to wówczas bowiem powołano tutaj filię warszawskiej Wolnej Wszechnicy Polskiej (WWP) ${ }^{23}$. Była to uczelnia niepaństwowa, nawiązująca nieco do modelu „wolnych uniwersytetów” popularnych w zachodniej Europie na przełomie wieków. Ze względu na dobór kadry naukowej oraz specyficzną atmosferę uczelni, powszechnie uważano WWP za domenę wpływów środowisk lewicowych i liberalnych. Łódzka filia WWP nie osiągnęła oszałamiającego sukcesu, liczba studentów oscylowała wokół 300-400 osób ${ }^{24}$. Działała też zbyt krótko, aby wpłynąć na jakąkolwiek zmianę oblicza robotniczego miasta. Mimo to, tradycja WWP odegrała bardzo istotną rolę podczas tworzenia po wojnie uniwersytetu w Łodzi, który w dużej mierze opierał się na środowisku łódzkich i warszawskich „wszechnicowców.”

Za uczynieniem Łodzi jednym z centrów powojennej odbudowy nauki polskiej przemawiało szereg pragmatycznych przesłanek. Niewielki stopień zniszczeń wojennych, stosunkowo dobre warunki życia (jak na skalę trudnych pierwszych powojennych miesięcy), oraz bliskość Warszawy wszystko to decydowało o tym, że do robotniczej Łodzi przyjechała w początkach 1945 roku bardzo liczna grupa intelektualistów, naukowców i artystów, a miasto na krótki czas stało się nieformalną stolicą polskiej kultury. Jednak o powołaniu w Łodzi uniwersytetu decydowały przede wszystkim przesłanki polityczne. Łatwiejszym wydawać się mogła budowa uczelni w miejscu nieobciążonym wcześniejszymi strukturami akademickimi - jak w wypadku Krakowa czy Poznania, łatwiejszym także zdawać się mogło nadanie mu ideowego oblicza oczekiwanego przez nowe władze. Duże znaczenie miał robotniczy charakter miasta $-\mathrm{z}$ jednej strony oczekiwać można było, że wpłynie on na demokratyzację i radykalizację nowotworzonego uniwersytetu, z drugiej zaś doskonale wpisywał się w cele propagandowe. Tworzenie Uniwersytetu przedstawiano jako akt dziejowej sprawiedliwości, wyrównanie krzywd, które Łódź przez dekady musiała cierpieć ze względu na swój polityczny radykalizm i proletariacki charakter. Jednocześnie miał to być symbol demokratycznych i egalitarnych przemian, niesionych przez projekt budowy Polski Ludowej ${ }^{25}$.

23 K. Baranowski, Oddziat Wolnej Wszechnicy Polskiej w Łodzi 1928-1939, Warszawa 1977.

24 Tamże, s. 74.

25 Podczas uroczystej inauguracji roku akademickiego w styczniu 1946 roku 
Dekret o utworzeniu Uniwersytetu Państwowego w Łodzi wydano 24 maja 1945 roku. Planowano, że pierwszym rektorem uczelni zostanie biolog, prof. Teodor Vieweger, pełniący przed 1939 rokiem funkcję rektora warszawskiej WWP, jednak zginął on w wypadku samochodowym dwa dni przed oficjalnym ogłoszeniem dekretu. Rektorem nowopowstałej uczelni został mianowany wobec tego filozof prof. Tadeusz Kotarbiński, przed wojną związany z Uniwersytetem Warszawskim. Kotarbiński był typem przedwojennego liberała, sympatyzującym raczej z lewym skrzydłem ówczesnej sceny politycznej. Jednocześnie mógł liczyć na znaczne poparcie przedwojennej kadry naukowej. Jego kandydatura miała wyraźnie kompromisowy charakter, godzić miała środowiska radykalne z tymi bardziej konserwatywnymi i sceptycznymi wobec nowych porządków. Miała także zachęcić niezdecydowanych profesorów do osiedlenia się w Łodzi.

Wizja uczelni prezentowana przez Kotarbińskiego nie była szczególnie rewolucyjna. Uniwersytet miał być przestrzenią nieskrępowanej dyskusji, wolnej od jakiegokolwiek ideologicznego balastu, której struktura jego zdaniem nie powinna odbiegać zbyt mocno od przedwojennych wzorców. Swój program pierwszy rektor UŁ streszczał następująco:

Uniwersytet Łódzki chce być dostępny głównie dla dzieci rodzin ze sfer pracujących, chce być szczerze postępowy (a to, że jest nowy, ułatwia mu uniezależnienie się od średniowiecznego balastu pokutującego w tradycji starych wszechnic), chce być zdecydowanie laicki, chce mieć wolną rękę wobec wszelkich sztywnych systemów ideologicznych, światopoglądowych, historiozoficznych i innych. Chce służyć prawdzie wedle najlepszego rozumienia każdego poszczególnego badacza i nauczyciela. Niechaj prawda wyłania się z rzetelnej i wolnej dyskusji rzeczowej ${ }^{26}$.

Uniwersytet miał być więc zdecydowanie apolityczny, a jego społeczna rola ograniczać miała się przede wszystkim do tworzenia odpowiednich warunków dla prowadzenia nieskrępowanej dyskusji naukowej. Tak bardzo istotny z punktu widzenia powojennego ładu problem pochodzenia

ówczesny wiceminister oświaty mówił: „Otwarcie Uniwersytetu Łódzkiego ma znaczenie symbolu. Łódź, miasto wielkie, dziś, po zburzeniu stolicy, największe w Polsce, nie mogła do r. 1939 uzyskać pełnej, normalnej szkoły akademickiej. [...] Dzień dzisiejszy, dzień inauguracji Uniwersytetu Łódzkiego, symbolizuje akt dziejowy społecznej sprawiedliwości, symbolizuje dążenie polskiej Demokracji do otwarcia bram szkół wyższych dla szerokich mas pracujących, symbolizuje zbliżenie wiedzy z pracą, symbolizuje współpracę robotnika przy warsztacie i naukowca na katedrze czy w laboratorium”, Archiwum Uniwersytetu Łódzkiego (dalej: AUŁ), Biuro Rektoratu, jedn. org. 1856, Przemówienie p. Wiceministra Wtadystawa Bieńkowskiego na uroczystej inanguracji roku akademickiego na Uniwersytecie Eódzkim dnia 13 stycznia 1946 roku.

26 Cyt. za P. Hübner, Kotarbiński versus Chatasiński. 
społecznego studentów traktowany był przez Kotarbińskiego ogólnikowo. Charakterystyczne, że nie był on, jak się wydaje, entuzjastą takich rozwiązań jak kursy przygotowawcze czy rok wstępny, pozwalający na podjęcie studiów bez matury, dedykowany przede wszystkim dla młodzieży robotniczej i chłopskiej, przed wojną i podczas okupacji mającej ograniczone możliwości podjęcia nauki w szkole średniej ${ }^{27}$.

\section{„Demokratyczny populista”}

Proponowana przez rektora wizja uniwersytetu nie wszystkim przypadła do gustu. Głównym jej oponentem był Józef Chałasiński, kierujący wówczas Katedrą Socjologii, pełniący równocześnie funkcję prorektora. Chałasiński pierwsze kroki w świecie nauki stawiał w latach dwudziestych w Poznaniu jako uczeń Floriana Znanieckiego. Rozgłos przyniosła mu przede wszystkim czterotomowa praca Mtode pokolenie chtopów (1938). Chałasiński, który pochodził z rodziny chłopskiej, nie czuł się najlepiej w przedwojennym środowisku uniwersyteckim. Jako polityczny radykał, sympatyzujący przed wojną z ruchem ludowym i orędownik demokratyzacji stosunków społecznych, nie mógł liczyć na przychylność raczej konserwatywnego świata polskiej akademii. Sam po latach wspominał:

Nie umiałem się zadomowić w sferach uniwersyteckiej inteligencji, ani ona mnie nie chciała, chociaż byłem już profesorem z grubymi książkami, ani mnie do niej nie ciągnęło. Nie umiałem pokochać nauki dla samego wykładania i pisania książek ${ }^{28}$.

Drugą Rzeczpospolitą Chałasiński oceniał zdecydowanie negatywnie. Krytykował utrwalenie społecznych nierówności, niezdolność do sformułowania jakichkolwiek projektów modernizacyjnych i konserwowanie wyraźnych barier klasowych. W latach okupacji pisał Chtopów i panów - książkę będącą gorzkim rozliczeniem z międzywojenną Polską. Najważniejsze jej tezy zaprezentował w wykładzie Społeczna genealogia inteligencji polskiej, wygłoszonym na uroczystej inauguracji pierwszego roku akademickiego na Uniwersytecie Łódzkim. Dla wielu obecnych na sali jego słowa mogły być szokujące:

27 Zob. Mtodzież akademicka o swoich potrzebach, „Dziennik Łódzki”, 25 XI 1946, s. 3.

28 Cyt. za W. Wincławski, Idea i socjologia uniwersytetu, w: Bunty i stużebności uczonego, s. 39.

Drugą Rzeczpospolitą Chałasiński oceniał zdecydowanie negatywnie. Krytykowat utrwalenie społecznych nierówności, niezdolność do sformułowania jakichkolwiek projektów modernizacyjnych i konserwowanie wyraźnych barier klasowych 
u nas każde pokolenie inteligencji rozpoczyna pracę od początku i zawsze w ten sam sposób. Zawsze ta sama frazeologia ratowania zachodnioeuropejskiej kultury polskiej, zawsze ta sama Polska - przedmurze chrześcijaństwa. Zawsze to samo nieróbstwo myślowe uświęcone jakimś wyświechtanym, górnolotnym frazesem.

W wydanej rok później książce, będącej zresztą próbą usystematyzowania rozważań z lat okupacji, pisał jeszcze ostrzej, że „inteligenckie getto to była ogromna siła reakcyjna, społeczna, pasożytująca na polskim życiu kulturalnym". To tradycyjną polską inteligencję czynił współodpowiedzialną za gospodarcze i technologiczne zacofanie Polski.

Tego typu wypowiedzi, w swym radykalizmie i krytycyzmie idące często zresztą dalej niż ówczesny oficjalny dyskurs PPR i władz centralnych, przyczyniać mogły się do utrwalenia nadanej Chałasińskiemu jeszcze przed wojną etykiety „marksisty”. Nie była to jednak prawda - jeśli mielibyśmy zakwalifikować jakoś jego poglądy, to chyba najlepszym byłoby określenie „demokratyczny populizm”, zaproponowane przez Antoninę Kłoskowską ${ }^{29}$, wychowankę Chałasińskiego. Najlepszy przykład takiego „demokratycznego populizmu”, z jednej strony krytycznego wobec polskiej tradycji, z drugiej polemicznego względem dyskursu oficjalnego, może być publicystyka Chałasińskiego z lat 1945-1948, której głównym wątkiem była reforma szkolnictwa wyższego i problem demokratyzacji uniwersytetów.

\section{Rewolucyjne eksperymenty, czyli jak uratować autonomię uczelni}

Tarcia pomiędzy dwoma rektorami, Kotarbińskim a Chałasińskim, rozpoczęły się już na samym początku współpracy. Socjolog bardzo ostro krytykował „zmodernizowany akademizm” Kotarbińskiego, a jego władzę nazywał w niektórych wystąpieniach wręcz dyktatorską. Konflikt miał wyraźny charakter programowy. Z perspektywy prowadzonej przez Chałasińskiego od lat przedwojennych krytyki „inteligenckiego getta", wizja liberalnego uniwersytetu Kotarbińskiego nie odpowiadała wyzwaniom i szansom powojennej rzeczywistości; „zmodernizowany akademizm”, pomimo pozorów „postępowości”, reprodukował model oderwanej od rzeczywistości, autonomicznej i apolitycznej „świątyni nauki”. Choć Chałasiński również był zwolennikiem zachowania au-

29 A. Kłoskowska, Bunty i stużebności uczonego, w: Bunty i stużebności uczonego, s. 15. 
tonomii szkół wyższych, sposób w jaki ową autonomię definiował, był - jak pokażemy dalej - zdecydowanie różny od sensu nadawanego jej przez Kotarbińskiego.

Zdaniem Chałasińskiego, ze względu na głębokie zmiany polityczne dokonujące się po wojnie, trwanie „liberalnego uniwersytetu” ${ }^{30}$ - jak go nazywał - musiało prowadzić do klęski polskiej nauki, ciosu będącego jednocześnie dotkliwym ciosem dla całego społeczeństwa. Cechą charakterystyczną uczelni starego typu była bowiem, według niego, skłonność do podkreślania wyraźnej separacji sfery nauki od bieżącego życia politycznego i społecznego. W toku rewolucyjnych przemian zachodzących po wojnie uniwersytet nie mógł dłużej trzymać się z dala od dokonujących się reform - wybór takiej drogi skazywał nie tylko na dalszą izolację, ale również na stopniową kolonizację przez dyskurs partyjno-biurokratyczny. Wybór ciasno rozumianej apolityczności prowadzić mógł, paradoksalnie, do upolitycznienia i podporządkowania władzy. Bierny, przywiązany do tradycyjnych zasad, a zarazem manifestujący nieufność wobec dokonujących się przemian uniwersytet skazany byłby, prędzej czy później, na konfrontację z władzą - jej wynik byłby z góry przesądzony na niekorzyść akademików. Chałasiński liczył natomiast, że środowisko uniwersyteckie nie tylko podejmie próbę obrony swych dotychczasowych uprawnień i przywilejów, lecz również zdobędzie się na wysiłek rozszerzenia swojej społecznej funkcji i nowego zdefiniowania własnej roli. Jeśli uniwersytet miał przetrwać i stać się miejscem żywej wymiany myśli - tak bardzo potrzebnym podczas dokonującej się politycznej i społecznej rewolucji - musiał podjąć walkę o własną podmiotowość i wypracować nową koncepcję działania. Postulowana przez Chałasińskiego reforma nie była więc próbą oportunistycznego dostrojenia się do dokonujących się przemian, lecz wyrazem nadziei związanych z możliwością realizacji radykalnych reform, połączonych z pragnieniem zabezpieczenia niezależności uniwersytetów w nowych warunkach politycznych ${ }^{31}$.

30 Innym znanym polskim socjologiem krytykującym ideę „uniwersytetu liberalnego" był Jan Szczepański, zob. J. Szczepański, Szkice o szkolnictwie wyższym, Warszawa 1976.

31 Apel do środowiska o podjęcie dyskusji dotyczącej reformy uniwersytetów - J. Chałasiński, O spoteczny sens reformy uniwersytetów, „Kuźnica” 1947, nr 24, s. 3.
W toku rewolucyjnych przemian zachodzących po wojnie uniwersytet nie mógł dłużej trzymać się z dala od dokonujących się reform - wybór takiej drogi skazywał nie tylko na dalszą izolację, ale również na stopniową kolonizację przez dyskurs partyjno-biurokratyczny. Wybór ciasno rozumianej apolityczności prowadzić mógł, paradoksalnie, do upolitycznienia i podporządkowania władzy 


\section{„Uniwersytet uspołeczniony”}

Program reformy szkolnictwa wyższego najpełniej wyłożył Chałasiński w obszernym artykule $O$ spoteczny sens reformy uniwersytetów ${ }^{32}$ z 1947 roku. Tekst ten można uważać za programowy dla modelu „uniwersytetu uspołecznionego", odpowiadającego, jego zdaniem, najlepiej wyzwaniom niesionym przez powojenne rewolucyjne lata. Dodajmy, że swoje poglądy na temat ideowego oblicza UŁ i roli, jaką powinien odegrać w życiu miasta, Chałasiński prezentował również w artykułach i wywiadach publikowanych na łamach łódzkiej prasy - wypowiedzi te miały znacznie bardziej popularny charakter, niemniej powtarzały te same myśli, które w zwarty sposób wyłożone zostały w programowej wypowiedzi $O$ spoteczny sens...

Podstawowym założeniem myślenia Chałasińskiego - zdawałoby się, że podobnie jak Kotarbińskiego - było dążenie do zachowania autonomii uniwersytetu, a docelową wizją porządku politycznego i społecznego, w którego ramach miały funkcjonować uczelnie, była demokracja, ugruntowana dzięki rozwiniętej opinii publicznej (czy jak czasem nazywa ją autor: opinii intelektualnej). W Polsce, gdzie tradycje samorządności i samoorganizacji były słabe, to właśnie na uniwersytetach spoczywać miała odpowiedzialność za budowę i kształtowanie opinii publicznej, stanowiącej z kolei najlepszą gwarancję stabilności i sprawności demokracji. Chałasiński zdawał się przekonany, że niezbędnym warunkiem realizacji demokracji ludowej jest swobodna dyskusja i konfrontacja różnorodnych opinii. Tak też wyobrażał sobie debatę na temat koniecznej w nowych warunkach przyszłej reformy szkolnictwa wyższego. Wierzył, że jego artykuł zainicjuje debatę, której efektem będzie sformułowanie społecznej wizji nowej uczelni, co tym samym pozwoli zapobiec narzuceniu zmian przez aparat państwowy.

Ważnym elementem tekstu jest - kilkakrotnie powtarzane - ostrzeżenie przed biurokratyzacją i pozbawieniem autonomii życia społecznego, a przede wszystkim uniwersytetów, które należą do tych dziedzin kultury, których autonomia powinna wzrastać w miarę upaństwowienia życia ekonomicznego ${ }^{33}$. Był to jasny i stanowczy komunikat do władz: z punktu widzenia demokracji, im silniejsze są tendencje do upaństwowienia innych dziedzin, tym jest bardziej konieczna pełna i wszechstronna autonomia nauki i kultury ${ }^{34}$.

32 Tamże; w podobnym tonie utrzymany był także artykuł Chałasińskiego pt. Problemy demokratyzacji, „Odrodzenie” 1947, nr 14-15 (123-124).

33 J. Chałasiński, O spoteczny sens reformy uniwersytetów, s. 3.

34 Tamże, s. 4. 
Jak przekonywał Chałasiński, zmiany społecznej można dokonywać dwoma metodami: w sposób rewolucyjny - odgórny i politycznie wydajny, jednak nierealizujący wartości demokratycznych, oraz za sprawą eksperymentów i stopniowej ewolucji. Gwałtowne rewolucyjne metody mogły sprawdzić się zaraz po wojnie, jak było choćby w przypadku reformy rolnej, lecz zmiany na uniwersytetach nie mogą być dokonywane w ten sposób. W tym obszarze życia społecznego potrzebna jest metoda eksperymentalna, wymagająca więcej czasu. Należy podjąć próbę budowy nowego typu instytucji, odpowiadającej swoim czasom. Jak kilkakrotnie podkreślał, ze względu na skostnienie środowiska akademickiego i niechęć wobec jakichkolwiek głębszych zmian, jedynie Łódź, robotnicze miasto bez uniwersyteckich tradycji, dawała odpowiednią przestrzeń dla takich eksperymentów. Niestety - przekonywał Chałasiński - rektor Kotarbiński, mimo tych sprzyjających okoliczności, działał bez wizji i zamiast odważyć się na eksperymenty wybrał wygodną drogę kompromisu z przedwojennym środowiskiem.

Wbrew opiniom swego ówczesnego przełożonego, Chałasiński podkreślał, że zadania uniwersytetu nie ograniczają się jedynie do sfery badań naukowych - w powojennej rzeczywistości powinien stać się on również niezależnym ośrodkiem kształtowania opinii publicznej, a przez to także podstawową instytucją budującej się demokracji ludowej, rozumianej tutaj właśnie w duchu „populistycznym”, o czym wspomnieliśmy wcześniej, nie zaś w konwencji charakterystycznej dla państwowej propagandy. Zdaniem Chałasińskiego, polskie uczelnie, pragnąc być „Świątyniami nauki”, nie podejmowały tej doniosłej społecznej roli. Tutaj też otwierało się pole dla - ograniczonej jednak tylko do tej dziedziny - rządowej interwencji, polegającej na ubraniu w formułę prawniczą i wcieleniu w życie przyszłej reformy, której celem miało być wprowadzenie uniwersytetu na właściwe drogi uspołecznienia i autonomii oraz skierowanie go ku wyzwaniom nowoczesnego społeczeństwa. Reforma ma służyć nadaniu społecznego sensu autonomii uniwersytetów, a nie jej likwidacji, a żeby tak się stało, musi być dziełem nie biurokracji, lecz samego środowiska akademickiego. Nowoczesnemu społeczeństwu, jak przekonywał Chałasiński, potrzebne są nie tylko laboratoria, lecz również ośrodki krystalizowania się opinii intelektualnej - jeśli uniwersytety nie ulegną demokratyzacji, nie podejmą wyzwania „intelektualizacji” społeczeństwa, stracą wpływ kształtowania nie tylko rzeczywistości, ale także intelektualnego oblicza nowej inteligencji. To zaś oznaczałoby koniec marzeń o prawdziwej ludowej demokracji.

Wizja „uniwersytetu uspołecznionego”, która wcielona miała zostać w życie najpierw na gruncie łódzkim, zakładała przekroczenie przedwo- 
Wizja „uniwersytetu uspotecznionego",

która wcielona miata zostać w życie najpierw

na gruncie tódzkim, zakładała przekroczenie przedwojennych obciążeń

i patologii środowiska naukowego. Chałasiński postulowat porzucenie

rzemieślniczego modelu pracy naukowej

ugruntowanego w hierarchicznym

i z natury

konserwatywnym

układzie mistrzuczeń oraz likwidację środowiskowych stosunków typowych

dla akademickich

grup towarzyskich, opartych na wzajemnej

uprzejmości

i powierzchownym szacunku jennych obciążeń i patologii środowiska naukowego. Chałasiński postulował porzucenie rzemieślniczego modelu pracy naukowej ugruntowanego w hierarchicznym i z natury konserwatywnym układzie mistrz-uczeń oraz likwidację środowiskowych stosunków typowych dla akademickich grup towarzyskich, opartych na wzajemnej uprzejmości i powierzchownym szacunku. Miejsce rytualnych dyskusji zająć miało rzeczywiste zainteresowanie pracą naukową kolegów i ostre, a tym samym twórcze, polemiki. Badania zespołowe, przełamanie izolacji poszczególnych środowisk naukowych i dynamiczna wymiana myśli zaowocują - przekonywał Chałasiński - nie tylko lepszymi wynikami, lecz również przygotują grunt pod przedefiniowanie roli nauki w „nowoczesnym społeczeństwie ludowym". Jego zdaniem tradycyjny model uniwersytetu - jako zrodzony na gruncie innych stosunków społecznych - jest nie do uratowania; społeczna reforma musi zakładać stworzenie uczelni zaangażowanej w proces przemian, jednak nie przez dogmatyczne propagowanie jednej teorii naukowej (chodziło tutaj zapewne o oficjalnie interpretowany marksizm), a przez krytyczną metodę myślenia naukowego, co uczyniłoby uniwersytet bezpartyjnym ośrodkiem opinii publicznej. Według Chałasińskiego, zreformowany uniwersytet to przestrzeń świadomej służby społeczeństwu i demokracji, nie zaś miejsce realizacji tylko indywidualnych zainteresowań w zamkniętej wspólnocie towarzyskiej.

W latach 1945-1948 Chałasiński szczerze angażował się w pracę nad odbudową polskiego życia naukowego i z determinacją walczył o uzyskanie przez środowisko akademickie sprawczości w procesie powojennych zmian. Prace redakcyjne w „Kuźnicy” czy „Myśli Współczesnej”, aktywność w Klubie Demokratycznym i podejmowanie licznych funkcji organizacyjnych świadczą o pragnieniu stania się podmiotem, a nie tylko przedmiotem dokonujących się zmian. Podobnie jak wielu intelektualistów, był przekonany, że uczestniczy w dziejowym eksperymencie, który mimo swych ujemnych stron, otwiera szansę na radykalne przyspieszenie procesów modernizacyjnych i przekroczenie utrwalonych podziałów społecznych. Charakterystyczne dla atmosfery tamtego okresu zdają się wspomnienia jego współpracownika z „Kuźnicy”, Jana Kotta:

Byliśmy pewni, że pisaniem zmieniamy historię, jakby do nas należała. Ciągle to „ukąszenie heglowskie”, ale nie znaliśmy wtedy tego terminu i to myśmy raczej kąsali historię. Jak wściekli. Jak demiurdzy powojennego czasu. Aż do zawrotu głowy. Wydawało się, że można wszystko lepić jak z gliny ${ }^{35}$.

35 J. Kott, Przyczynek do biografii, Londyn 1990, s. 213. 
Wkrótce jednak okazać się miało, że artykuły i przemówienia lewicowych intelektualistów mają nikłą szansę, by „zmieniać historię”. Mniej więcej w chwili publikacji artykułu $O$ spoteczny sens reformy uniwersytetów środowisko naukowe zaczynało tracić jakąkolwiek moc sprawczą. Chałasiński zapewne nie zdawał sobie wówczas jeszcze sprawy z tego, że „łagodna rewolucja” dobiega powoli końca. Charakterystyczne, że w tym samym numerze „Kuźnicy”, w którym opublikowano programowy tekst Chałasińskiego, pojawiła się również (na pierwszej stronie, jeszcze przed artykułem socjologa, umieszczonym w dalszej części numeru!) polemika z jego tezami, sygnowana przez autorytatywnego przedstawiciela władz - Stefana Jędrychowskiego. Tytuł polemiki był bardzo wymowny: Walka o wolność nauki czy o utrzymanie starego porządku? Chałasiński mógł orientować się, że na niezależność jest coraz mniej miejsca, wciąż chyba jednak wierzył, że dokonujące się przemiany polityczne da się wykorzystać z pożytkiem dla polskiego uniwersytetu. Ceną, jaką trzeba było zapłacić, aby odzyskać zaufanie władz, był opublikowany pod koniec 1947 roku artykuł pt. Wspótczesne reformy szkolne a idea narodu i socjalizmu, gdzie dotychczas głoszone tezy uzupełnił jednoznacznie pozytywnymi ocenami szkolnictwa radzieckiego ${ }^{36}$. Wkrótce okazać się miało, że podobne kompromisy będą konieczne coraz częściej.

\section{Rektor Chałasiński - wizje a realia}

Na razie jednak zdawać się mogło, że pozycja Chałasińskiego jest coraz silniejsza. W 1949 roku w miejsce Kotarbińskiego, który już dawno utracił poparcie władz, objął stanowisko rektora UŁ. Czas konfrontacji reformatorskich wizji z praktyką nadszedł jednak w najmniej odpowiednim momencie - władze krok po kroku podporządkowywały sobie naukę i uniwersytety. Dramatyczna walka o zachowanie rzeczywistego sensu reformatorskich pomysłów nie mogła w tych warunkach skończyć się powodzeniem.

Mimo wszystko od samego początku Chałasiński nie szczędził wysiłków, aby podkreślić doniosłość zachodzących za jego kadencji zmian. Zgodnie z zapowiedziami przełamania ram „inteligenckiego getta”, inauguracja roku akademickiego 1949/1950 odbyła się przed rektoratem, w publicznej przestrzeni miasta, dodatkowo w obecności przedstawicieli łódzkich robotników. Podczas uroczystości Chałasiński mówił:

36 R. Herczyński, Spętana nauka, s. 88. 
Robotnicy i Przodownicy pracy, Profesorowie i Pracownicy UŁ, Młodzieży, Obywatele [...]. Nieprzypadkowo z naszą uroczystością wyszliśmy poza mury uniwersytetu, na otwarte miejsce publiczne. Zaznaczamy w ten sposób, że z całą świadomością zrywamy z tradycją społecznego izolacjonizmu uniwersytetu, zaznaczamy w ten sposób, że twórcza myśl naukowa włączy się w potężny nurt przeobrażeń naszego polskiego życia we wszystkich jego dziedzinach. Tą manifestacją przełamania izolacji uniwersytetu otwieramy ten nowy rok akademicki ${ }^{37}$.

Chałasiński jako rektor podjął z władzami swego rodzaju grę - jej stawką była obrona choćby szczątkowej niezależności uczelni połączona z próbą uratowania części elementów składających się na projekt „uniwersytetu uspołecznionego”. Dzisiejszy badacz nie jest w stanie oddzielić instytucjonalnej mimikry koniecznej do utrzymania stanowiska od rzeczywistego entuzjazmu w stosunku do niektórych reform czy włączania własnych inicjatyw. Przykład takich trudności może stanowić choćby analiza mocno zideologizowanego przemówienia na inauguracji roku akademickiego 1950/1951, w którym Chałasiński krytykował swobodny tok studiów, optując za unifikacją i parametryzacją. Obok sformułowań typowych dla ówczesnego oficjalnego dyskursu władz, pojawiały się tam również te same argumenty, które formułował w swoich krytykach tradycyjnego uniwersytetu jeszcze przed wojną oraz w pierwszych latach powojennych. Analizując jego wypowiedzi od przełomu 1948 i 1949 roku, można jednak zauważyć, że coraz silniej pobrzmiewa w nich partyjna nowomowa, odwołania do PZPR stają się coraz częstsze, a pozytywnym punktem odniesienia jest Związek Radziecki. Chałasiński zaczyna używać języka władz zarówno do prezentowania własnych pomysłów, jak i do budowania politycznie poprawnej fasady.

Rok akademicki 1949/1950 - czyli pierwszy rok kadencji Chałasińskiego - był dla Łodzi i UŁ przełomowy, jednak nie tak, jak wyobrażał to sobie nowo wybrany rektor. Jeszcze pod koniec 1948 roku, wraz z postępującą odbudową Warszawy, Łódź doświadczyła gwałtownego odpływu części mieszkańców, zwłaszcza inteligencji. Wielu pozostających „, tranzycie” wracało do domu ${ }^{38}$, a dotyczyło to przede wszystkim środowisk twórczych - literatów, artystów i właśnie profesorów. Nawet aktywne środowisko łódzkich marksistów (skupione wokół „Myśli Współczesnej” i „Kuźnicy” ) utraciło prym na rzecz Warszawy,

37 J. Chałasiński, Inauguracja V roku akademickiego Uniwersytetu Łódzkiego, w: Materiaty do dziejów Uniwersytetu Łódzkiego (1945-1950), red. B. Baranowski, K. Duda-Dziewierz, Łódź 1952, s. 239.

38 Tranzytem przez Łódź, red. I. Bołtuc-Staszewska, Łódź 1964. 
a Uniwersytet Warszawski zaczął walczyć z U€ o tytuł uniwersytetu najbardziej zaangażowanego na rzecz nowego porządku politycznego ${ }^{39}$.

W tych warunkach Chałasiński rozpoczął swoją reformę uczelni. Program uspołecznionego uniwersytetu uległ oczywiście, ze względów politycznych, znacznemu uszczupleniu. Jego oś stanowiło dążenie do zwiększeniu udziału studentów pochodzenia chłopskiego i robotniczego (co wiązało się również z modyfikacją metod nauczania). Ponadto Chałasiński dążył do demokratyzacji stosunków pomiędzy kadrą i studentami, nawiązania mocniejszych więzi między środowiskiem akademickim a załogami łódzkich fabryk, oraz do zwiększenia wpływu uczelni na oblicze miasta, co manifestowało się m. in. w ambitnych planach budowy osiedla akademickiego. Choć nie było już mowy o „bezpartyjnym ośrodku opinii intelektualnej” i autonomii uniwersytetu, można zakładać, że w pierwszych miesiącach swojej kadencji Chałasiński realizował głównie swoją wizję, choć zapewne w poczuciu ciągłego nadzoru ze strony władz. Jednak przygotowywane na szczeblu centralnym reformy nauki powoli wchodziły w życie; logika systemu stalinowskiego nie pozwalała na realizację autorskich projektów. Na realizację koncepcji „uspołecznionego uniwersytetu” brakło czasu i poparcia ze strony środowiska akademickiego.

\section{Koniec marzeń - „socjalistyczna idea uniwersytetu”}

Wcielana w życie od końca 1949 roku reforma szkolnictwa wyższego oznaczała degradację UŁ, który zakwalifikowano do grupy uniwersytetów prowincjonalnych. Liczba studentów UŁ - także z powodu wydzielenia wydziałów medycznych i uczynienia z nich osobnej uczelni - spadła ponad trzykrotnie, do 1523 w roku akademickim 1955/1956 wobec 5572 studentów w roku 1948/1949 ${ }^{40}$. Wśród kadry naukowej krążyć zaczęły plotki o likwidacji całej uczelni, a przynajmniej o rozwiązaniu kierunków humanistycznych, a także - w innej wersji o przeniesieniu katedr do Torunia. UŁ jako uniwersytet prowincjonalny zamiast dotychczasowych czternastu kierunków humanistycznych prowadził nabór jedynie na filozofię, filologię polską, filologię rosyjską, oraz - po interwencji nestorki polskiej historiografii marksistowskiej Natalii Gąsiorowskiej - także na historię ${ }^{41}$. Socjologię, najważniejszą

39 B. Baranowski, K. Baranowski, Trudne lata Uniwersytetu Eódzkiego.

40 Tamże.

41 Uniwersytet Eódzki: Historia. Teraźniejszość. Perspektywy, red. B. Baranowski, Łódź 1987, s. 11. 
z perspektywy rektora Chałasińskiego, zlikwidowano. Większość katedr nadal funkcjonowała, ale wstrzymano ich działalność dydaktyczną. „Uniwersytet uspołeczniony” zamieniał się w uniwersytet w stanie likwidacji...

Jak już zauważyliśmy, wypowiedzi Chałasińskiego jako rektora znacznie różnią się od tych z pierwszych lat powojennych. Klamrą spinającą tę ewolucję jest przemówienie zatytułowane Od liberalnej do socjalistycznej idei uniwersytetu, wygłoszone w 1950 roku z okazji pięciolecia UŁ. „Uspołeczniony uniwersytet” zamienił się w „uniwersytet socjalistyczny”, a stare tezy rektora powtórzone zostały przy tej okazji w innym kontekście, w nowym języku i zazwyczaj w ostrzejszym tonie.

Pierwsza część przemówienia to rozbudowana, przeprowadzona w sposób bardziej systematyczny niż dotychczas, krytyka tradycyjnego modelu uniwersytetu, sprzyjającego reprodukcji „inteligenckiego getta”, traktującego naukę utylitarnie jako źródło zysku albo wyrafinowaną formę arystokratycznej zabawy. Powtórzona została krytyka polityki rektora Kotarbińskiego, obecnego zresztą podczas wygłaszania przemówienia $^{42}$. Odnosząc się do przewodniego hasła Kotarbińskiego - „Prawda i Wolność”, Chałasiński mówił:

Dochodzenie do prawdy i korzystanie z wolności przez jednostki nie było przecież nigdy bezkierunkowe, lecz zawsze wiązało się z pozytywnie określonym kierunkiem zainteresowań epoki [...]. Uniwersytet Łódzki jest historycznym nonsensem, jeżeli ma być pojęty jako przedwojenny Uniwersytet Warszawski przeniesiony do Łodzi w udoskonalonej liberalnej wersji [...] uniwersytet nie tylko stoi na polu walki klasowej, ale sam w niej bierze udział. Świadomość tego faktu jest nieodzowna do tego, aby uniwersytety przestały być rezerwatami zabytków, a stały się ośrodkami kształtującej się socjalistycznej kultury intelektualnej ${ }^{43}$.

Chałasiński dokonał nie tylko rozliczenia z Kotarbińskim, ale i samokrytyki, przyznając, iż także dał się uwieść liberalnej koncepcji uniwersytetu. Chciał wolności od faszyzmu (który stał się metonimią wszystkiego, co wsteczne, hierarchiczne i autorytarne), nie dostrzegając, że tak pojęta wolność nie musi wcale prowadzić do socjalizmu - ale już dzisiaj nie wiedzieć nam tego nie wolno ${ }^{44}$. Raz jeszcze Chałasiński

42 Jak wynika z odpowiedzi Kotarbińskiego, Chałasiński udostępnił mu treść przemówienia kilkanaście dni wcześniej.

43 J. Chałasiński, Od liberalnej do socjalistycznej idei Uniwersytetu, „Życie Nauki" 1950, nr 7-8, s. 526-529.

44 Tamże, s. 533. 
rekonstruował liberalną wizję uniwersytetu, kładąc nacisk na te same elementy, co w swych wystąpieniach sprzed kilku lat, jednak ostrzej i bardziej surowo. Przede wszystkim nie było już mowy o demokracji i autonomii jako kluczowych punktach odniesienia. Wolność publicznej wypowiedzi i swobodna dyskusja zostały skrytykowane jako pobłażanie naukowym nonsensom i źle rozumiana tolerancja. Chałasiński szydził z typu liberalnego intelektualisty uważającego, że spełnił swoją misję, wypowiadając publicznie swe poglądy i dyskutując je ze swymi środowiskowymi kolegami, jednocześnie, że społeczeństwo ukształtuje się samoistnie i harmonijnie. To jednak recepta na społeczeństwo kapitalistyczne (czyli społeczeństwo nieudane), ale nie na społeczeństwo socjalistyczne, które wymaga naczelnych ośrodków kierowniczych opinii publicznej we wszystkich sprawach, nie wyłączając spraw nauki ${ }^{45}$.

Zmiana w stosunku do wcześniejszych wypowiedzi na temat opinii publicznej jest uderzająca, Chałasiński podkreślał dosadnie: koniec z nauką jako prywatną własnością, pełnić musi ona publiczne funkcje. Potrzebne są ramy instytucji, których zadaniem jest z jednej strony „kierowanie swobodną dyskusją intelektualistów”, a z drugiej informowanie społeczeństwa o tym, co w sprawach nauki jest ustalone jako uzgodniony pogląd uczonych, a co jest przedmiotem kontrowersji między nimi ${ }^{46}$.

Wolność nauki, stanowiąca aksjomat wcześniejszych poglądów Chałasińskiego, została teraz uznana za wolność kapitalistyczną, nieodpowiednią i szkodliwą dla społeczeństwa socjalistycznego. Przejaw takiej wolności bez odpowiedzialności przed społeczeństwem stanowiły na przykład niefrasobliwe odejścia profesorów UŁ, którzy nieraz z dnia na dzień porzucali swoje katedry w Łodzi dla lepszych posad w stolicy. W ten sposób wolność niepoddana nadzorowi ze strony instytucji państwa okazywała się krokiem na drodze ku anarchii.

Poprzednie postulaty intelektualizacji społeczeństwa zostały także zaostrzone, Chałasiński pisał wyraźnie, że demokratyzacja nie może polegać na upowszechnieniu kultury klas wyższych, ale na stworzeniu zupełnie nowego typu kultury odpowiadającej dążeniom i doświadczeniom mas ludowych. Pamiętamy, że wcześniej zwracał uwagę raczej na konieczność tworzenia nowych typów instytucji, sprzyjających demokratyzacji życia intelektualnego; zaś kultura i takie wartości jak pluralizm i demokracja zdawały się pozostawać uniwersalnymi.

45 Tamże, s. 537-538.

46 Tamże, s. 538. 


\begin{tabular}{|c|c|c|c|}
\hline & $\begin{array}{l}\text { LIBERALNY } \\
\text { UNIWERSYTET }\end{array}$ & $\begin{array}{l}\text { USPOŁECZNIONY } \\
\text { UNIWERSYTET }\end{array}$ & $\begin{array}{l}\text { SOCJALISTYCZNY } \\
\text { UNIWERSYTET }\end{array}$ \\
\hline TYP UCZONEGO & $\begin{array}{l}\text { intelektualny } \\
\text { arystokrata }\end{array}$ & $\begin{array}{l}\text { lider opinii } \\
\text { publicznej }\end{array}$ & $\begin{array}{l}\text { budowniczy } \\
\text { społeczeństwa } \\
\text { socjalistycznego } \\
\text { („humanista } \\
\text { socjalistyczny”) }\end{array}$ \\
\hline $\begin{array}{l}\text { MIEJSCE } \\
\text { WSPOŁECZEŃSTWIE }\end{array}$ & $\begin{array}{l}\text { izolowany } \\
\text { od społeczeństwa } \\
\text { skierowany } \\
\text { „do wewnątrz", } \\
\text { skupiony } \\
\text { na własnych } \\
\text { problemach } \\
\text { i ezoterycznie } \\
\text { pojmowanej nauce }\end{array}$ & $\begin{array}{l}\text { blisko związany } \\
\text { ze społeczeństwem } \\
\text { i jego problemami } \\
\text { skierowany } \\
\text { „na zewnątrz”, } \\
\text { świadom swej } \\
\text { doniosłej funkcji } \\
\text { w nowoczesnym } \\
\text { społeczeństwie }\end{array}$ & $\begin{array}{l}\text { jeden } \\
\text { z instrumentów } \\
\text { przekształcania } \\
\text { społeczeństwa } \\
\text { relacjonuje } \\
\text { społeczeństwu } \\
\text { rozwój wiedzy } \\
\text { naukowej } \\
\text { i formułuje } \\
\text { obowiązujące } \\
\text { interpretacje }\end{array}$ \\
\hline ZADANIA & $\begin{array}{l}\text { uprawianie nauki } \\
\text { „Czystej” } \\
\text { tworzenie } \\
\text { przestrzeni dla } \\
\text { nieskrępowanej } \\
\text { dyskusji naukowej }\end{array}$ & $\begin{array}{l}\text { działalność } \\
\text { badawcza } \\
\text { ważny ośrodek } \\
\text { opinii publicznej }\end{array}$ & $\begin{array}{l}\text { realizuje } \\
\text { „historyczne } \\
\text { zadania nauki” } \\
\text { w planowy sposób } \\
\text { przekształca } \\
\text { stosunki klasowe } \\
\text { w dziedzinie nauki }\end{array}$ \\
\hline KADRA NAUKOWA & $\begin{array}{l}\text { model } \\
\text { rzemieślniczy - } \\
\text { „mistrz i uczeń” } \\
\text { rozwój młodego } \\
\text { pracownika } \\
\text { naukowego } \\
\text { interesuje tylko } \\
\text { jego „mistrza” } \\
\text { wstrzemięźliwa } \\
\text { w awansowaniu } \\
\text { pracowników }\end{array}$ & $\begin{array}{l}\text { model kolektywu } \\
\text { - bez wyraźnego } \\
\text { podziału } \\
\text { na „mistrzów” } \\
\text { i „uczniów” } \\
\text { rozwój młodego } \\
\text { pracownika } \\
\text { naukowego } \\
\text { przedmiotem } \\
\text { zainteresowania } \\
\text { całego wydziału } \\
\text { odmłodzona kadra } \\
\text { sprzyja awansom } \\
\text { uzdolnionych } \\
\text { naukowców }\end{array}$ & $\begin{array}{l}\text { model fabryki - } \\
\text { określona z góry } \\
\text { liczba kształconych } \\
\text { badaczy } \\
\text { ściśle zaplanowany } \\
\text { rozwój młodego } \\
\text { pracownika } \\
\text { naukowego }\end{array}$ \\
\hline
\end{tabular}




\begin{tabular}{|c|c|c|c|}
\hline & $\begin{array}{l}\text { LIBERALNY } \\
\text { UNIWERSYTET }\end{array}$ & $\begin{array}{l}\text { USPOLECZNIONY } \\
\text { UNIWERSYTET }\end{array}$ & $\begin{array}{l}\text { SOCJALISTYCZNY } \\
\text { UNIWERSYTET }\end{array}$ \\
\hline ORGANIZACJA & $\begin{array}{l}\text { luźna federacja } \\
\text { katedr }\end{array}$ & $\begin{array}{l}\text { ścisła więź między } \\
\text { katedrami (tworzą } \\
\text { instytuty badawcze } \\
\text { w obrębie } \\
\text { wydziału) } \\
\text { nacisk na badania } \\
\text { zespołowe } \\
\text { i realizację } \\
\text { projektów } \\
\text { badawczych przez } \\
\text { członków różnych } \\
\text { katedr }\end{array}$ & $\begin{array}{l}\text { nacisk na badania } \\
\text { zespołowe } \\
\text { podporządkowanie } \\
\text { poszczególnych } \\
\text { dyscyplin filozofii } \\
\text { społecznej }\end{array}$ \\
\hline KONCEPCJANAUKI & $\begin{array}{l}\text { uprawianie nauki } \\
\text { to poznanie dla } \\
\text { samego poznania, } \\
\text { może odbywać } \\
\text { się w całkowitej } \\
\text { izolacji } \\
\text { od społeczeństwa } \\
\text { nauka jako } \\
\text { prywatna własność } \\
\text { uczonych } \\
\text { pluralizm teorii } \\
\text { naukowych }\end{array}$ & $\begin{array}{l}\text { uprawianie } \\
\text { nauki wiąże się } \\
\text { ze zobowiązaniami } \\
\text { wobec } \\
\text { społeczeństwa } \\
\text { idea nauki } \\
\text { ma nieklasowy } \\
\text { charakter, jest } \\
\text { uniwersalna, } \\
\text { ogólnoludzka } \\
\text { pluralizm teorii } \\
\text { naukowych }\end{array}$ & $\begin{array}{l}\text { klasowy charakter } \\
\text { nauki } \\
\text { nauka to dobro } \\
\text { publiczne, służy } \\
\text { rozwojowi } \\
\text { socjalistycznego } \\
\text { społeczeństwa } \\
\text { dominująca rola } \\
\text { marksizmu }\end{array}$ \\
\hline $\begin{array}{l}\text { STOSUNEK } \\
\text { WZGLEEDEM WŁADZ } \\
\text { PAŃSTWOWYCH }\end{array}$ & ścisła izolacja & $\begin{array}{l}\text { autonomia } \\
\text { względem } \\
\text { biurokracji }\end{array}$ & $\begin{array}{l}\text { w sferze nauki } \\
\text { realizuje } \\
\text { ogólną linię } \\
\text { polityczną władz } \\
\text { państwowych }\end{array}$ \\
\hline $\begin{array}{l}\text { SKŁAD KLASOWY } \\
\text { ISTOSUNEK } \\
\text { WOBEC } \\
\text { DEMOKRATYZACJI }\end{array}$ & $\begin{array}{l}\text { dominuje młodzież } \\
\text { pochodzenia } \\
\text { inteligenckiego, } \\
\text { burżuazyjnego } \\
\text { i ziemiańskiego } \\
\text { procesy } \\
\text { demokratyzacji } \\
\text { są mu obojętne }\end{array}$ & $\begin{array}{l}\text { dominuje młodzież } \\
\text { pochodząca } \\
\text { z warstw ludowych } \\
\text { i inteligencji } \\
\text { pracującej } \\
\text { aktywnie } \\
\text { wspiera procesy } \\
\text { demokratyzacji } \\
\text { życia społecznego }\end{array}$ & $\begin{array}{l}\text { wyraźnie oparty } \\
\text { na młodzieży } \\
\text { robotniczej } \\
\text { i chłopskiej } \\
\text { jest jednym } \\
\text { z narzędzi } \\
\text { przekształcenia } \\
\text { struktury klasowej }\end{array}$ \\
\hline
\end{tabular}

Tabela 1

Trzy modele uniwersytetu obecne w programowych tekstach Józefa Chałasińskiego z lat 1945-1950. 
„Demokratyczny

populista", wierzący jeszcze przed kilku laty w możliwość oddolnej,

demokratycznej

reformy uniwersytetu,

przekonywał się

do racjonalności

i konieczności projektu, jakim był stalinizm

To właśnie poczucie

rozczarowania, zawodu, osamotnienia i niezrozumienia było ceną, jaką przyszło zapłacić części polskich lewicowych intelektualistów za ich marzenia o demokratycznej, prawdziwie ludowej i nowoczesnej Polsce. Powojenna rewolucja niosła złudną nadzieję na ich realizację. Ona również tę nadzieję ostatecznie odebrała
Prezentując zebranym „socjalistyczną ideę uniwersytetu”, Chałasiński zdawać już musiał sobie sprawę z tego, że jego reformatorskie wizje, z takim zapałem propagowane do 1948 roku, nie mają szans realizacji ${ }^{47}$. Być może z poczucia rozczarowania i bezsiły, jakie musiało się z tym wiązać, wynikała skierowana przez niego w lipcu 1950 roku prośba do Ministra Szkół Wyższych i Nauki o zwolnienie ze stanowiska rektora ${ }^{48}$. Dymisji nie otrzymał. Na fotelu rektora UŁ zasiadał jeszcze przez dwa lata, dołączając swój głos do chóru entuzjastów dokonującej się wówczas odgórnej reformy uniwersytetów obliczonej na całkowite podporządkowanie nauki państwowej biurokracji. Jak wynikałoby z późniejszych wspomnień Chałasińskiego, jego zaangażowanie w tym okresie nie wypływało, jak w wypadku części środowiska akademickiego, z konformizmu i pragnienia dostosowania się do nowych warunków działania. „Demokratyczny populista”, wierzący jeszcze przed kilku laty w możliwość oddolnej, demokratycznej reformy uniwersytetu, przekonywał się do racjonalności i konieczności projektu, jakim był stalinizm. W latach sześćdziesiątych napisze o sobie w tamtym okresie, że był już wtedy nie tylko „rewolucjonistą humanizmu socjalistycznego”, ale też „ministrantem ustalonego obrządku - kultu Stalina” ${ }^{49}$, którym został

działaniem nawyku aktywności z rzeczywistymi efektami, nawyku roboty w jakimkolwiek obrządku, byle - w samym sobie i w uniwersyteckim środowisku liberalnym - nie akceptować zastoju, zadowalającego się kontemplacją wierności własnemu duchowemu pięknu, lecz uczestniczyć w dokonującej się rewolucji społecznej ${ }^{79}$.

Z powodu zachowania pewnej samodzielności sądów i wyraźnej niechęci do zabiegania o własną instytucjonalną karierę (nigdy nie wstąpił do PZPR), Chałasiński mimo wszystko nie zyskał sobie pełnego zaufania władz. Z drugiej strony zaś jako autor koncepcji „uspołecznionego uniwersytetu”, a później szczerze zaangażowany we wdrażanie reform rektor UŁ, przez sporą część środowiska naukowego traktowany był z dystansem, jako nadgorliwy radykał, który torował drogę stalinizmowi na polskim uniwersytecie. To właśnie poczucie rozczarowania, zawodu, osamotnienia i niezrozumienia było ceną, jaką przyszło zapłacić części polskich lewicowych intelektualistów

47 Zob. W. Wincławski, Idea i socjologia uniwersytetu, s. 42-43.

48 AUŁ, Biuro Rektoratu, sygn. 298, Memoriał Rektora ws. warunków pracy i rozwoju UŁ.

49 Tranzytem przez Eódź, s. 79. 
za ich marzenia o demokratycznej, prawdziwie ludowej i nowoczesnej Polsce. Powojenna rewolucja niosła złudną nadzieję na ich realizację. Ona również tę nadzieję ostatecznie odebrała. 
KAMIL PISKAŁA - doktorant w Katedrze Najnowszej Historii Polski UŁ. Jego zainteresowania badawcze koncentrują się wokół historii polskiej lewicy XIX i XX wieku, symbolicznych aspektów funkcjonowania ruchu robotniczego, a także tradycji środkowoeuropejskiego marksizmu. Ponadto zajmuje się dziejami polskiej międzywojennej myśli politycznej, teoriami rewolucji oraz peryferyjnymi dyskursami modernizacyjnymi pierwszej połowy XX stulecia. Młodość spędza zgarbiony nad zakurzonymi papierami $\mathrm{w}$ archiwum albo starymi książkami w bibliotecznych czytelniach. Związany z łódzkim klubem „Krytyki Politycznej”, w „Praktyce Teoretycznej” redaktor tematyczny w zakresie nauk historycznych.

AGATA ZYSIAK - socjolożka kultury, doktorantka w Katedrze Socjologii Kultury UŁ, gdzie pisze pracę na temat powojennej modernizacji Polski i demokratyzacji nauki. W swoich badaniach zajmuje się nowoczesnością, pamięcią i biografią oraz socjologią historyczną. Założycielka Stowarzyszenia Topografie, gdzie od 2009 roku koordynuje Archiwum Pamięci Łodzian, członkini Polskiego Stowarzyszenia Historii Mówionych.

\section{Dane adresowe autorek:}

Kamil Piskała

Katedra Historii Polski Najnowszej UŁ

ul. Kamińskiego 27a, 90-219 Łódź

e-mail: kamil.piskala@gmail.com

Agata Zysiak

Katedra Socjologii Kultury UŁ

ul. Rewolucji 1905 nr 41, 90-214 Łódź

e-mail: agatazysiak@gmail.com

\section{Cytowanie:}

K. Piskała, A. Zysiak, Świątynia nauki, fundament demokracji czy fabryka specjalistów?, „Praktyka Teoretyczna” nr 3(9)/2013 http:// www.praktykateoretyczna.pl/PT_nr9_2013_Po_kapitalizmie/11. Piskala,Zysiak.pdf (dostęp dzień miesiąc rok)

Authors: Kamil Piskała, Agata Zysiak

Title: A Temple of Knowledge, a Foundation of Democracy or an Expert's Factory? Józef Chałasiński and the Postwar Discussion about the Idea of University Abstract: First postwar years in the history of Poland was crucial time of doubts 
and hopes for building a new world and a new society. It is worth remembering, that in the first years it was not known how the history of Poland is going to be shaped and many intellectuals believed to have an unique chance to make a world better place. The interwar academic tradition was confronted with ideas of building a new type of university - the modernization dreams took many forms, occurring to be strong factor of a split between radical and moderate option. Soon those dreams have met with brutal reality and universities were transformed to important places in communist state, where national history, ideology and future elite was reproduced and shaped.

We would like to focus on personalities of Józef Chałasiński and Tadeusz Kotarbiński, whose biographies met in the city of Lodz in 1945 - the place where new university was being built for the new times. Analyzing press materials, official statements and scientific papers we aim to reconstruct models of university - models as propositions of creating a new academia in a changing sociopolitical frames.

Keywords: Józef Chałasiński, models of university, Stalinism, postwar Poland, Łódź 